Inteligensi: Jurnal Ilmu Pendidikan Vol. 2, No.1, 2019. Hal 9-19

Tersedia online di https://jurnal.unitri.ac.id/index.php/inteligensi

ISSN 2656-601X (online)

ISSN 2656-8675 (cetak)

\title{
KORELASI ANTARA HASIL TES LISAN DENGAN HASIL TES TERTULIS PADA MAHASISWA PGSD UNRAM
}

\author{
Itsna Oktaviyanti ${ }^{1}$, Awal Nur Kholifatur Rosyidah ${ }^{2}$ \\ ${ }^{1,2}$ Program Studi PGSD, FKIP, Universitas Mataram \\ E-mail: itsna@unram.ac.id
}

\begin{abstract}
The purpose of this study was to determine the correlation between oral test results with the written test results of PGSD UNRAM students. The approach used in this research is quantitative with the type of correlation research. The population was all of second semester studentsm using sampling technique of simple random sampling, the samples obtained amounted to 180. Data collection techniques used were oral tests and written tests. Data analysis techniques using descriptive statistical analysis and Product Moment correlation. The results showed that: 1) oral test results were included in both categories with an average of 79.6; (2) written test results are included in both categories with an average of 78.65; and (3) there is a correlation between the learning outcomes of oral tests with the written learning outcomes of PGSD UNRAM students. Students who understand the concept of the material, have good social studies learning outcomes between oral tests and written tests. Both types of tests can be varied implementation, according to time, conditions, and type of material to be tested.
\end{abstract}

Keywords: learning outcomes; oral test; written test.

\begin{abstract}
ABSTRAK
Tujuan penelitian ini untuk mengetahui korelasi antara hasil tes lisan dengan hasil tes tertulis mahasiswa PGSD UNRAM. Pendekatan yang digunakan dalam penelitian ini adalah penelitian kuantitatif dengan jenis penelitian korelasi. Populasi penelitian adalah seluruh mahasiswa semester dua dengan teknik pengambilan sampel menggunakan simple random sampling, yang berjumlah 180. Teknik pengumpulan data berupa tes lisan dan tes tertulis. Teknik analisis data menggunakan analisis statistik deskriptif dan korelasi Product Moment. Hasil penelitian menunjukkan bahwa: 1) hasil tes lisan termasuk dalam kategori baik dengan rata-rata sebesar 79,6; (2) hasil tes tertulis termasuk dalam kategori baik dengan rata-rata 78,65; dan (3) terdapat korelasi antara hasil belajar tes lisan dengan hasil belajar tes tertulis mahasiswa PGSD UNRAM. Mahasiswa yang paham akan konsep materi, memiliki hasil belajar IPS yang baik antara tes lisan dengan tes tertulis, begitu juga sebaliknya. Kedua jenis tes tersebut pengimplementasiannya dapat divariasikan, menyesuaikan dengan waktu, dan kondisi, serta jenis materi yang akan diujikan.
\end{abstract}

Kata kunci: hasil belajar; tes lisan; tes tertulis.

\section{PENDAHULUAN}

Undang-Undang Nomor 20 Tahun 2003 pasal 39 ayat 2 tentang Sistem Pendidikan Nasional menyatakan bahwa pendidik adalah tenaga profesional yang bertugas merencanakan dan melaksanakan proses pembelajaran, menilai hasil pembelajaran, melakukan bimbingan dan pelatihan, serta melakukan penelitian dan pengabdian kepada masyarakat, terutama bagi pendidik pada perguruan tinggi. Berdasarkan pengertian tersebut tampak jelas salah satu tugas seorang pendidik adalah menilai hasil pembelajaran.

Pendidik dalam hal ini bisa seorang guru atau seorang dosen, sesuai jenjang pendidikan yang diampu. Baik guru

Cara mengutip: Oktaviyanti, I., \& Rosyidah, A.N.K. (2019). Korelasi Antara Hasil Tes Lisan dengan Hasil Tes Tertulis pada Mahasiswa PGSD UNRAM. Inteligensi: Jurnal Ilmu Pendidikan, 2(1), 9-19 
maupun dosen, sama-sama berkewajiban menilai hasil pembelajaran. Melalui penilaian tersebut seorang pendidik bisa melakukan refleksi dan evaluasi terhadap kualitas pembelajaran yang telah dilakukan. Sehingga dapat diketahui apakah pembelajaran ter-sebut berhasil atau tidak (Mutaqqin dan Kusaeri, 2017: 2). Penilaian hasil pembelajaran bisa dilakukan dengan teknik tes dan non tes. Namun, bentuk penilaian tes paling sering digunakan dibandingkan alat ukur non tes (Ruhimat, 2018: 185-186). Teknik tes terdiri dari tiga bentuk yaitu tes tertulis, tes lisan dan tes tindakan (performance).

Tes tertulis yaitu tes yang menuntut peserta didik menulis jawaban yang dibutuhkan, sedangkan tes lisan merupakan bentuk tes yang menuntut peserta didik untuk menjawab secara lisan. Kedua bentuk tes ini digunakan untuk mengukur atau menilai hasil belajar peserta didik pada ranah pengetahuan. Seperti halnya pernyataan Saidah (2016: 23) bahwa penilaian pada ranah pengetahuan menggunakan instrumen penilaian dalam bentuk tes tulis, tes lisan, observasi diskusi, tanya jawab dan percakapan, dan penugasan. Kedua tipe tes ini mempunyai kekurangan dan kelebihan (Fitrani, 2013: 5). Tes tulis mempunyai ke-lebihan lebih respektif me-wakili isi dan luas bahan, serta lebih mudah dan cepat cara memeriksanya karena dapat menggunakan kunci tes bahkan alat-alat hasil kemajuan teknologi. Kekurangannya yaitu: (1) persiapan untuk menyusun jauh lebih sulit, terutama pada tes tulis bentuk uraian karena soalnya banyak dan harus teliti untuk menghindari kelemahan-kelemahan lain; (2) soal-soal cenderung untuk mengungkapkan ingatan dan daya pengenalan kembali dan sulit untuk mengukur proses mental yang tinggi;
(3) kerjasama antar siswa pada waktu pengerjaan lebih terbuka.

Tes lisan mempunyai kelebihan seperti: (1) dapat menilai kemampuan dan tingkat pengetahuan peserta didik, sikap, serta kepribadiannya karena dilakukan secara berhadapan langsung; (2) bagi peserta didik yang kemampuan berpikirnya relatif lambat sehingga sering mengalami kesukaran dalam memahami pernyataan soal, tes bentuk ini dapat menolong sebab peserta didik dapat menanyakan langsung kejelasan pertanyaan yang dimaksud; (3) hasil tes dapat langsung diketahui peserta didik. Selain mempunyai kelebihan tes lisan mempunyai kekurangan antara lain: (1) subjektivitas pendidik sering mencemari hasil tes; (2) waktu pelaksanaan yang diperlukan terlalu banyak. Subjektivitas terjadi karena sebagaian besar pendidik tidak menggunakan kriteria penilaian tes lisan yang jelas. Hal tersebut sejalan dengan data awal yang dimiliki oleh Wicaksono dkk (2016: 59), data yang diperoleh menjelaskan bahwa beberapa guru di enam SD Negeri di Kota Semarang yang notabene di kota besar masih belum mengguna-kan kriteria penilaian yang jelas dalam kegiatan evaluasi pembelajar-an sehingga penilaian yang di-laksanakan tidak dapat dilakukan seobyektif mungkin.

Berdasarkan kelebihan dan kekurangan yang dimiliki oleh tes lisan dan tes tertulis, pendidik perlu mencoba kedua bentuk tes tersebut untuk mengukur hasil baik guru maupun dosen mengkreasikan belajar agar lebih valid. Maka dari itu tidak ada salahnya bentuk penilaian hasil belajar dengan menggunakan tes lisan dan tertulis. Selain kedua tes tersebut, Samad (2013: 95) mengungkapkan bahwa:

"there are new methods of assessment have been developed to exhibit what 
students learn and their ability to use their existence knowledge to facilitate their own learning in the classroom".

Maksudnya adalah ada metode penilaian baru yang telah dikembangkan untuk menunjukkan apa yang dipelajari siswa dan kemampuan mereka dalam menggunakan pengetahuan mereka untuk memfasilitasi pembelajaran mereka sendiri di kelas. Namun pada penelitian ini, lebih fokus untuk penggunaan teknik penilaian tes lisan dan tes tertulis sebagai instrumen penilaian hasil belajar. Hal tersebut dirasa perlu untuk memfasilitasi berbagai tipe peserta didik baik siswa sekolah dasar hingga mahasiswa yang belajar perguruan tinggi.

Ada banyak tipe anak di dalam menjalani penilaian hasil belajar. Sebagian besar anak lebih nyaman menggunakan tes tertulis karena dirasa lebih memiliki banyak waktu untuk berpikir dan tidak merasa terintimidasi ketika berhadapan langsung dengan guru atau dosennya. Selain itu, tipe anak seperti ini cenderung memiliki kepercayaan diri yang rendah. Penyebab utama kepercayaan diri yang rendah yaitu karena kurangnya kesempatan bagi peserta didik untuk berbicara saat proses pembelajaran. Hal tersebut karena pendidik terlalu mendominasi pada setiap proses pembelajaran. Sehingga perlu meningkatkan kemampuan dalam mengorganisir proses pembelajaran agar memberi-kan kesempatan kepada peserta didik lebih aktif, sehingga kualitas pembelajaran akan lebih baik. Hal tersebut sejalan dengan hasil penelitian tindakan kelas yang dilakukan oleh Purwanta (2016: 163) bahwa peningkatan yang signifikan pada kemampuan guru menghasilkan peningkatan kualitas pembelajaran. Kualitas pembelajaran yang baik akan terjadi jika pendidik menyadari kekurangan yang dilihat dari hasil penilaian. Karena penilaian yang ideal, sejatinya tidak hanya ditujukan untuk mengukur para peserta didik, melainkan hasilnya dapat dijadikan umpan balik bagi guru untuk memperbaiki proses pembelajaran selanjutnya (Ruhimat, 2018: 178). Di sisi lain, ada tipe anak yang lebih menyukai bentuk tes lisan karena merasa lebih menguasai materi dan percaya diri untuk dapat menjawab dengan tepat. Selain itu, tipe anak seperti ini merasa tes lisan lebih adil karena tidak memberi kesempatan kepada peserta didik untuk berbuat curang dalam me-ngerjakan tes.

Hal tersebut juga terjadi pada mahasiswa semester II program studi PGSD Universitas Mataram. Saat peneliti menawarkan bentuk tes yang akan dilakukan untuk penilaian hasil belajar, sebagian besar mahasiswa lebih memilih bentuk tes tertulis karena merasa tidak percaya diri. Akibat dari tidak percaya diri dapat menyebabkan rasa gugup yang pada akhirnya menghambat kinerja otak, sehingga semua materi yang telah dipelajari menjadi hilang. Namun, untuk kalangan mahasiswa lain yang selalu aktif selama proses per-kuliahan, mereka lebih memilih menggunakan bentuk tes lisan. Selain menghindari kecurangan, alasan yang diberikan diantaranya karena mahasiswa merasa ada banyak hal yang ingin diungkapkan melalui jawaban secara lisan dan sulit untuk dituangkan dalam bentuk tulisan.

Fakta tersebut diperkuat dengan hasil penilaian mahasiswa pada kegiatan perkuliahan di semester sebelumnya. Dari hasil nilai mahasiswa, meskipun banyak yang mendapatkan nilai tinggi saat tes lisan dan tes tertulis, ada beberapa mahasiswa yang mendapatkan nilai tinggi saat tes lisan 
namun rendah saat tes tertulis. Hal sebaliknya juga terjadi, beberapa mahasiswa tidak dapat menjawab dengan benar saat dilakukan tes lisan namun mampu mendapat nilai tinggi saat tes tertulis. Ada banyak yang menjadi penyebab fenomena tersebut diantaranya pe-nguasaan materi pada mahasiswa, kondisi mahasiswa saat tes, kepercayaan diri, dan tingkat kesulitan soal yang diberikan (Silviriyanti, 2019: 16-17).

Dari latar belakang yang telah dipaparkan, peneliti tertarik untuk meneliti mengenai korelasi antara nilai hasil tes lisan dengan tes tertulis. Untuk selanjutnya dapat diajadikan pilihan keputusan bagi dosen maupun sebagai tambahan informasi mengenai bentuk instru-men tes (tertulis atau lisan) yang sekiranya efektif untuk diterapkan ketika melakukan penilaian proses dan hasil belajar pada mahasiswa.

\section{METODE PENELITIAN}

Penelitian ini menggunakan pendekatan penelitian kuantitatif dengan jenis penelitian korelasi, yaitu untuk mencari hubungan antara hasil tes lisan dan hasil tes tertulis pada mahasiswa PGSD UNRAM. Menurut Arikunto (2010: 247248), penelitian korelasional (Correlational Studies) merupakan penelitian yang dimaksudkan untuk mengetahui ada tidaknya hubungan antara dua atau beberapa variabel. Hal tersebut sejalan dengan pendapat Sukardi (2019: 212) bahwa penelitian korelasi merupakan suatu penelitian yang melibatkan pe-ngumpulan data guna menentukan, apakah ada hubungan dan tingkat hubungan antara dua variabel atau lebih.

Populasi dalam penelitian ini adalah seluruh mahasiswa semester dua PGSD Universitas Mataram yang berjumlah 328 mahasiswa. Teknik pengambilan sampel yang dilakukan yaitu Simple Random Sampling dengan menggunakan rumus Slovin, eror margin sebesar 5\%, kemudian didapatkan sampel berjumlah 180.Teknik pengumpulan data yang digunakan adalah tes lisan dan tes tertulis. Variabel yang digunakan dalam penelitian ini terdiri dari dua variabel, yaitu variabel terikat hasil tes tertulis (Y) dan variabel bebas yaitu tes lisan $(\mathrm{X})$. Instrumen penelitian berupa soal tes lisan dan soal tes tertulis. Soal tes lisan terdiri dari 5 soal yang telah melalui uji validitas dan reliabilitas. Pengujian validitas dan reliabilitas didapatkan dari uji coba kepada mahasiswa di luar sampel.

Seperti halnya soal tes lisan, untuk instrumen penilaian tes tertulis juga melalui tahap uji validitas dan uji reliabilitas. Bahkan sebelum sampai pada uji validitas dan reliabilitas, instrumen soal didasar-kan dari perumusan kisi-kisi soal. Hal tersebut dilakukan untuk menghindari instrumen yang kurang baik karena tidak memenuhi syarat. Tes tertulis yang disediakan yaitu 20 soal, kemudian diujicobakan pada mahasiswa di luar sampel. Hasil dari uji coba tersebut diuji validitas dan reliabilitasnya, kemudian diambil 10 soal sebagai instrumen penilaian tes tertulis. Teknik analisis data menggunakan analisis statistik deskriptif dan analisis korelasi product moment. Prasyarat analisis yang digunakan yaitu uji normalitas data.

\section{HASIL DAN PEMBAHASAN}

Penelitian ini bertujuan untuk mengetahui korelasi antara hasil tes lisan dengan hasil tes tertulis. Data yang dianalisis yaitu hasil belajar mahasiswa semester dua mata kuliah Pendidikan IPS SD, program studi PGSD, Universitas Mataram. Hasil belajar didapatkan dari dua 
teknik yaitu tes lisan dan tes tertulis. Adapun aspek yang dianalisis dalam penelitian ini diantaranya yaitu analisis statistik hasil tes lisan, analisis statistik hasil tes tertulis dan analisis korelasi antara hasil tes lisan dan hasil tes tertulis. Untuk menganalisis ketiga aspek tersebut, perlu adanya instrumen untuk mengukurnya. Instrumen yang dibutuhkan yaitu lembar soal untuk menilai kemampuan mahasiswa dalam menjawab tes lisan dan lembar soal untuk menilai hasil belajar dengan tes tertulis.

Soal tes lisan dan soal tes tertulis terlebih dahulu diujicobakan sebelum digunakan. Uji coba dilakukan kepada mahasiswa diluar sampel untuk mendapatkan soal yang valid dan reliabel. Uji validitas dan reliabilitas dihitung dengan meng-gunakan SPSS versi 17. Berikut hasil uji validitas dan reliabilitas soal tes lisan.

\begin{tabular}{cll}
\multicolumn{3}{c}{ Tabel 1. Rekapitulasi Uji Validitas Soal Uji } \\
Coba Tes Lisan \\
\hline $\begin{array}{c}\text { Nomor } \\
\text { Soal }\end{array}$ & $\begin{array}{c}\text { Pearson } \\
\text { Correlations }\end{array}$ & \multicolumn{1}{c}{ Validitas } \\
\hline 1 & .349 & Tidak Valid \\
2 & $.618^{*}$ & Valid \\
3 & .499 & Tidak Valid \\
4 & $.586^{*}$ & Valid \\
5 & $.570^{*}$ & Valid \\
6 & .349 & Tidak Valid \\
7 & $.618^{*}$ & Valid \\
8 & .499 & Tidak Valid \\
9 & $.586^{*}$ & Valid \\
10 & $.570^{*}$ & Valid \\
\hline
\end{tabular}

Data pada tabel di atas menunjukkan bahwa sebanyak 6 butir soal dinyatakan valid. Soal yang valid kemudian diuji reliabilitas dengan cronbach's alpha. Pada uji reliabilitas, digunakan batas tertentu untuk menentukan reliabel tidaknya suatu instrumen. Batasan nilai reliabilitas menurut Sekaran (1992) dalam Priyatno
(2010: 98) yaitu, reliabilitas kurang dari 0,6 adalah kurang baik, sedangkan 0,7 dapat diterima, dan di atas 0,8 adalah baik. Hasil uji reliabilitas menunjukkan nilai cronbach's alpha sebesar 0,770. Mengacu pada pendapat Sekaran, nilai 0,770 berarti di atas 0,6, sehingga instrumen soal sudah terbukti reliabel dan dapat diterima. Kemudian, setelah melakukan uji validitas dan reabilitas, 6 soal yang valid dan realiabel diambil 5 soal dengan tingkat kevalidan yang lebih tinggi untuk digunakan yaitu no 2, 4, 5, 7 dan 9 .

Sementara hasil uji validitas dari soal tes tertulis disajikan pada Tabel 2 seperti di bawah ini.

Tabel 2. Rekapitulasi Uji Validitas Soal Uji Coba Tes Tertulis

\begin{tabular}{lll}
\hline $\begin{array}{c}\text { No. } \\
\text { soal }\end{array}$ & \multicolumn{1}{c}{$\begin{array}{c}\text { Pearson } \\
\text { Correlations }\end{array}$} & \multicolumn{1}{c}{ Validitas } \\
\hline 1 & $.549^{*}$ & Valid \\
2 & $.593^{* *}$ & Valid \\
3 & $.713^{* *}$ & Valid \\
4 & .016 & Tidak Valid \\
5 & .181 & Tidak Valid \\
6 & .075 & Tidak Valid \\
7 & $.549^{*}$ & Valid \\
8 & $.567^{* *}$ & Valid \\
9 & .249 & Tidak Valid \\
10 & $.536^{*}$ & Valid \\
11 & .069 & Tidak Valid \\
12 & $.549^{*}$ & Valid \\
13 & $.657^{* *}$ & Valid \\
14 & -038 & Tidak Valid \\
15 & .093 & Tidak Valid \\
16 & .144 & Tidak Valid \\
17 & $.559^{*}$ & Valid \\
18 & $.676^{* *}$ & Valid \\
19 & .071 & Tidak Valid \\
20 & .295 & Tidak Valid \\
\hline
\end{tabular}

Data pada tabel di atas menunjukkan bahwa sebanyak 10 butir soal valid. Soal yang valid kemudian diuji reliabilitas dengan cronbach's alpha. Hasil uji reliabilitas pada hasil tes tertulis menunjukkan nilai cronbach's alpha sebesar 0,843. Nilai 0,843 lebih besar dari 
0,6 , sehingga instrumen soal tes tertulis terbukti reliabel dan dapat diterima. Setelah melakukan uji validitas dan reliabilitas, peneliti menentukan soal yang digunakan untuk penelitian.Dari 20 soal yang diujicobakan, 10 soal dinyatakan valid dan reliabel. Jumlah tersebut sesuai dengan soal yang dibutuhkan untuk penilaian tes tertulis yaitu 10 soal. Soal yang dipakai diantaranya yaitu soal nomer 1, 2, 3, 7, 8, 10, 12, 13, 17, dan 18.

Setelah didapatkan instrumen yang valid untuk penilaian tes lisan dan tes tertulis, selanjutnya dilakukan analisis statistik hasil tes lisan, analisis statistik hasil tes tertulis dan analisis korelasi antara hasil tes lisan dan hasil tes tertulis.

a) Hasil Tes Lisan

Tes lisan dilakukan dengan memberi pertanyaan secara lisan kepada masingmasing mahasiswa secara bergantian. Tes lisan mem-butuhkan penguasaan materi agar dapat menjawab pertanyaan yang diberikan. Pertanyaan yang diberikan sebanyak 5 soal dengan rentang bobot soal 1 sampai 5 tergantung ketepatan dalam menjawab.

Setelah melalui proses tes lisan, didapatkan hasil sebagai berikut:

Tabel 3. Distribusi Frekuensi Penilaian Hasil Tes Lisan (variabel X)

\begin{tabular}{|c|c|c|c|}
\hline Nilai & Kategori & $\mathrm{F}$ & Prosentase \\
\hline 80 & Baik & 114 & $63,3 \%$ \\
\hline 100 & Sekali & & \\
\hline $70-79$ & Baik & 22 & $12,2 \%$ \\
\hline $60-69$ & Cukup & 30 & $16,6 \%$ \\
\hline$<60$ & Kurang & 14 & $7,8 \%$ \\
\hline
\end{tabular}

Dari tabel di atas dapat diketahui bahwa (1) Rentang nilai 80-100 termasuk dalam kategori sangat baik dengan frekuensi mahasiswa sebanyak 114 (63,3\%); (2) Rentang nilai 70-79 termasuk dalam kategori baik dengan frekuensi mahasiswa sebanyak 22 mahasiswa (12,2\%); (3) Rentang nilai 60-69 termasuk dalam kategori cukup dengan frekuensi sebanyak 30 mahasiswa (16,6\%); (4) Rentang nilai $<60$ termasuk dalam kategori kurang dengan frekuensi mahasiswa sebanyak 14 mahasiswa (7,8\%). Kemudian didapatkan nilai rata-rata hasil tes lisan mahasiswa PGSD UNRAM semester II sebesar 79,6 termasuk dalam kategori baik.

Banyaknya mahasiswa yang mendapat nilai tes lisan pada kategori kurang tidak hanya disebabkan kurangnya pengusaan materi, melainkan juga kepribadian siswa yang tertutup. Berbeda dengan mahasiswa yang terbuka, mahasiswa tipe ini akan lebih memungkinkan untuk menjawab pertanyaan dengan lancar. Hal tersebut sejalan dengan pendapat Elfiza (2017: 44):

"personality is one of internal factors that influence students' achievements in learning especially in speaking. Personality extrovert and introvertinfluences how the students handle the feelings that are evoked during the learning process".

Maksudnya adalah kepribadian merupakan salah satu faktor internal yang mempengaruhi prestasi siswa dalam belajar terutama keterampilan berbicara. Kepribadian ekstrovert dan introvert memengaruhi bagai-mana siswa menangani perasaan yang ditimbulkan selama proses pembelajaran.

Di lain sisi, mayoritas maha-siswa mendapat nilai tes lisan pada kategori baik sekali. Hal tersebut tidak terlepas oleh metode pem-belajaran yang selama ini dilakukan yaitu presentasi dan diskusi.Kegiatan presentasi dan diskusi dapat melatih mahasiswa untuk berkomunikasi secara langsung sehingga saat diadakan tes lisan, maha-siswa sudah 
terbiasa. Jika mahasiswa memiliki keterampilan komunikasi atau berbicara yang baik maka maha-siswa tersebut telah mampu untuk berpikir secara logis, sistematis, dan analisis (Tyaningsih, 2016: 56). Ketika mahasiswa diberikan pertanyaan secara tes lisan, maka akan mampu memahami dengan baik maksud dari pertanyaan tersebut dibarengi dengan keterampilan menjawab sesuai dengan konsep materi perkuliahan IPS yang telah diberikan.

Di samping itu, diperolehnya nilai tes lisan yang tinggi antara rentang 80-100 (berkategori baik sekali) dikarenakan pada proses pembelajaran telah mengimplementasikan strategi belajar siswa aktif, yaitu secara ber-kelompok mendiskusikan isu terkait dengan topik materi yang sedang diajarkan. Hal tersebut didukung oleh hasil penelitian Devira (2016: 13) bahwa pelaksanaan pembelajaran menggunakan metode investigasi kelompok dapat meningkatkan keterampilan berkomunikasi peserta didik di kelas IX SMP Negeri 2 Bukittinggi.

Melalui diskusi peserta didik dituntut untuk berkomunikasi, menjawab pertanyaan, atau tanggapan yang diajukan oleh peserta diskusi,dan menanggapi hasil penyajian kelompok lain. Kelas diskusi dimaksudkan untuk memberi dan menerima informasi antara dosen dengan mahasiswa, maupun mahasiswa dengan mahasiswa tentang topik terkini yang menjadi perhatian di kelas. Rahman et al., (2011: 86) berpendapat bahwa

"discussion method is characterized by probing questions from the teacher designed to elicit student interpretations, opinions, and questions."

Mengajar dengan diskusi dapat menjadikan cara yang efektif untuk membantu mahasiswa menerapkan ide-ide abstrak dan berpikir kritis tentang apa yang dipelajari. Sehingga dirasa tepat jika diimplementasikan pada ilmu sosial untuk melatih siswa berkomunikasi lisan.

b) Hasil Tes Tertulis

Sama seperti tes lisan, tes tertulis juga membutuhkan penguasan materi untuk dapat menjawab pertanyaan yang diberikan. Perbedaan dari kedua tes tersebut, tes tertulis lebih memiliki waktu lama dalam berpikir sehingga kesempatan untuk men-jawab pertanyaan dengan benar jauh lebih besar, sedangkan tes lisan memberi sedikit waktu untuk berpikir namun memberi kesempatan kepada mahasiswa untuk menjelas-kan jawaban yang lebih argumentatif sehingga menjadi pertimbangan bagi peneliti dalam pemberian nilai. Berikut hasil penilaian tes tertulis pada mata kuliah Pendidikan IPS SD semester 2 mahasiswa PGSD UNRAM:

Tabel 4. Distribusi Frekuensi Kemampuan Menjawab Tes Tertulis (variabel Y)

\begin{tabular}{llll}
\hline Nilai & Kategori & F & Prosentase \\
\hline $80-100$ & Baik & 98 & $54,4 \%$ \\
& Sekali & & \\
$70-79$ & Baik & 45 & $25 \%$ \\
$60-69$ & Cukup & 35 & $19,4 \%$ \\
$<60$ & Kurang & 2 & $1,1 \%$ \\
\hline
\end{tabular}

Dari tabel di atas dapat diketahui bahwa (1) Rentang nilai 80-100 termasuk dalam kategori sangat baik dengan frekuensi mahasiswa sebanyak 98 mahasiswa $(54,4 \%)$. (2) Rentang nilai 7079 termasuk dalam kategori baik dengan fekuensi mahasiswa sebanyak 45 mahasiswa (25\%); (3) Rentang nilai 60-69 termasuk dalam kategori cukup dengan frekuensi mahasiswa sebanyak 35 mahasiswa (9,4\%); (4) Rentang nilai $<60$ termasuk dalam kategori kurang dengan frekuensi mahasiswa sebanyak 2 
mahasiswa $(1,1 \%)$. Kemudian didapatkan nilai rata-rata kemampuan menjawab soal tes tertulis mahasiswa PGSD UNRAM semester II sebesar 78,65 termasuk dalam kategori baik.

Pada tes tertulis, masih ada mahasiswa yang mendapatkan nilai pada kategori kurang. Hal tersebut disebabkan karena kesalahan konseptual dimana mahasiswa sudah memahami konsep dari materi yang diujikan namun tidak bisa menuangkan konsep tersebut dalam tulisan sehingga terjadi kesalahan pada analisis konsep yang dipaparkan. Hal tersebut sejalan dengan hasil penelitian mengenai denah, yaitu kesalahan-kesalahan yang dilakukan oleh siswa dalam menyelesaikan soal tentang denah yaitu kesalahan konseptual dan kesalahan prosedural. Kesalahan konseptual yang dilakukan diantaranya dalam hal menganalisa konsep, menyebutkan konsep, dan kekeliruan mengaitkan konsep. (Perkasan dan Izzati, 2018: 51-52).

Berkaitan dengan hal di atas, bahwa proses pemahaman konsep merupakan bagian dari struktur mengkonstruksi pengetahuan. Sands (2014: 8) menjelaskan bahwa hal yang perlu dilakukan adalah fokus terhadap kesalahpahaman konsep dengan cara menilai secara kualitatif dan kuantitatif ketika mengevaluasi pengetahuan siswa. Artinya ketika jawaban kurang sesuai, maka bisa diperbaiki kembali dengan instrumen tes lainnya. Sehingga mahasiswa mengetahui letak kesalahpahaman konsep tersebut.

Dari data yang telah dipapar-kan di atas, terlihat bahwa rata-rata nilai hasil tes lisan lebih tinggi daripada nilai hasil tes tertulis. Hal tersebut disebabkan oleh beberapa faktor, diantaranya yaitu : (1) soal pada tes lisan cenderung memancing mahasiswa untuk berargumen, sehingga tidak terikat pada konsep secara utuh; (2) mahasiswa terbiasa untuk berargumen saat proses perkuliahan, sehingga tes lisan bukanlah hal baru yang membuat mereka kesulitan; (3) sebagian besar mahasiswa merasa mengetahui jawaban pada pertanyaan, namun sulit menuangkannya dalam bentuk tulisan. Beberapa alasan tersebut membuat hasil tes lisan lebih tinggi daripada tes tertulis, meskipun tidak signifikan.

Hasil penelitian ini berbeda dengan penelitian yang dilakukan oleh Rokhmawan (2009: 57) yaitu setelah menjalani proses belajar dengan metode yang sama, kelompok eksperimen I diberi tes tertulis dan kelompok eksperimen II diberi tes lisan, kelompok eksperimen I mempunyai rata-rata nilai hasil belajar yang lebih tinggi atau lebih baik dari pada ratarata nilai hasil belajar dari kelompok eksperimen II. Besarnya perbedaan hasil belajarnya adalah $8.50 \%$. Berdasarkan kriteria perbedaan hasil belajar menunjukkan bahwa perbedaan hasil belajar antara tes tertulis dengan tes lisan dalam kategori sangat rendah.

Selain hasil penelitian di atas, penelitian lain pada mata pelajaran biologi juga menyatakan bahwa hasil belajar siswa yang menggunakan tes tulis rata-ratanya lebih tinggi dibanding tes lisan, rata-rata tes tulis 74,43 dan tes lisan dengan rata-rata 64,02 (Fitriani, 2013: 7).

c) Korelasi antara Hasil Tes Lisan dengan Hasil Tes Tertulis.

Setelah memiliki data me-ngenai hasil penilaian tes lisan dan hasil penilaian tes tertulis, langkah selanjutnya yaitu menentukan korelasi anatara kedua variabel tersebut. Uji hipotesis mengenai korelasi antara hasil tes lisan dengan hasil tes tertulis 
diawali dengan melakukan uji prasyarat analisis yaitu uji normalitas data.

Hasil perhitungan uji normalitas kedua variabel menggunakan uji kolmogorof-Smirnov yang dihitung dengan bantuan SPSS 17 menyajikan nilai signifikansi sebesar 0,508. Berdasarkan kriteria pengujiannya, data berdistribusi normal karena taraf signifikasi $>0,05$.

Setelah didapatkan data hasil tes lisan dan hasil tes tertulis berdistribusi normal, selanjutnya dihitung korelasi antara kedua variabel menggunakan rumusan korelasi Product Moment dibantu dengan program SPSS 17. Berikut hasil analisis korelasinya.

Tabel 5. Uji Hipotesis (Korelasi)

\begin{tabular}{|c|c|c|c|}
\hline & & $\begin{array}{l}\text { Nilai Tes } \\
\text { Lisan }\end{array}$ & $\begin{array}{l}\text { Nilai Tes } \\
\text { Tertulis }\end{array}$ \\
\hline Nilai & Pearson & & \\
\hline Tes & Correla & & \\
\hline \multirow[t]{3}{*}{ Lisan } & tion & 1 & $.538^{* *}$ \\
\hline & $\begin{array}{l}\text { Sig. (2- } \\
\text { tailed) }\end{array}$ & & 0 \\
\hline & $\mathrm{N}$ & 180 & 180 \\
\hline Nilai & Pearson & & \\
\hline Tes & Correla & & \\
\hline \multirow[t]{3}{*}{ Tertulis } & tion & $.538^{* *}$ & 1 \\
\hline & $\begin{array}{l}\text { Sig.(2- } \\
\text { tailed) }\end{array}$ & 0 & \\
\hline & $\mathrm{N}$ & 180 & 180 \\
\hline
\end{tabular}

Berdasarkan tabel di atas, diketahui hasil uji hipotesis koefisien korelasi dengan sampel 180 mahasiswa dan taraf signifikan $5 \%$ diperoleh $\mathrm{r}$ hitung $>\mathrm{r}$ tabel yaitu 0,538 $>0,159$ dan nilai signifikansi sebesar 0,01 sehingga dilihat dari dasar pengambilan keputusan pada penelitian ini yaitu jika nilai signifikan $<0,05$ maka $\mathrm{H}_{\mathrm{a}}$ diterima dan $\mathrm{H}_{\mathrm{o}}$ ditolak, artinya ada korelasi antara kemampuan menjawab soal tes lisan dengan tes tertulis.

Korelasi tersebut dibuktikan dengan mahasiswa yang dianggap mampu ketika menjawab soal secara lisan, maka kemampuan untuk mengungkapkan dalam bentuk tulisan juga sistematis dan lebih tearah. Hasil penelitian oleh Kumara (2001: 38) menjelaskan bahwa ada hubungan positif antara kemampuan komunikasi lisan dengan kualitas ekspresi tulis. Siswa yang memiliki kemampuan verbal (berkomunikasi secara lisan) yang tinggi memiliki proses ingatan yang efisien, terutama dalam mengumpulkan informasi. Tingginya skor komunikasi lisan menggambarkan pengetahuan perbendaharaan kata yang luas dan kemampuan menyusun paragraf yang memadai.

Mahasiswa yang memiliki kemampuan verbal memungkinkan untuk bisa berkomunikasi atau men-jelaskan argumen secara lisan mapun tertulis berdasarkan pandangan dan pendapatnya sendiri secara nalar. Dikarenakan paham terhadap konsep materi ajar. Jika mahasiswa paham maka ada proses untuk mengetahui dan mengingat akan konsep materi IPS yang telah diberikan. Diperkuat oleh pendapat Murniayudi, Mustadi, \& Jerusalem (2018: 175) bahwa mahasiswa dikatakan paham akan konsep jika terjadi proses men-transfer pengetahuan maupun pengertian secara lisan atau tertulis mengenai suatu fenomena ke dalam berbagai macam kondisi yang sudah dianalisis sebelumnya melalui cara belajar maupun cara berpikir suatu ilmu. Sehingga informasi yang ingin digali oleh dosen dari mahasiswa terkait konsep IPS dapat tersampaikan dengan baik. Walaupun tidak semuanya, tetapi sebagian besar mahasiswa seperti itu adanya. Hal tersebut menandakan bahwa ada korelasi atau ada hubungan antara kemampuan menjawab tes lisan dengan tes tertulis. 
Berdasarkan nilai rata-rata mahasiswa dari kedua tes tersebut diperoleh 79,6 untuk rata-rata hasil tes lisan. Sementara untuk tes tertulis diperoleh ratarata sebesar 78,65. Keduanya termasuk dalam katagori baik. Pada implementasinya jika dilihat dari nilai rata-rata kedua tes tersebut tidak terlalu jauh berbeda. Tidak ada jenis instrumen yang dianggap paling baik untuk dilaku-kan penilaian proses dan hasil belajar mahasiswa. Artinya pemilihan instru-men harus menyesuaikan dengan waktu dan kondisi, serta jenis materi yang akan diujikan. Dikatakan efektif jika instrumen tersebut dapat mengukur indicator dan tercapainya tujuan pembelajaran.

Pemberian jenis instrumen kepada mahasiswa untuk dilaksanakan tes lisan maupun tertulis dikembalikan lagi pada tujuannya. Lebih baik lagi penggunaan antara keduanya divariasikan. Sehingga pemberian instrument akan dirasa tepat diberikan. Hal ini menghindari agar mahasiswa tidak menjadi pihak yang dirugikan hanya karena kurang sesuai jenis tes yang diberikan. Padahal secara konsep mahasiswa mampu untuk mendeskripsikan.

\section{SIMPULAN}

Berdasarkan hasil analisis data dan pembahasan yang telah diuraikan, maka dapat disimpulkan bahwa: (1) hasil tes lisanmahasiswa PGSD Unram termasuk dalam kategori baik dengan rata-rata sebesar 79,6; (2) hasil tes tertulis mahasiswa PGSD Unram termasuk dalam kategori baik dengan rata-rata 78,65; (3) ada korelasi antara hasil belajar tes lisan dengan hasil belajar tes tertulis. Mahasiswa yang paham akan konsep materi, memiliki hasil belajar IPS yang baik antara tes lisan dengan tes tertulis. Hal yang perlu dicermati adalah pemilihan instrumen baik tes lisan maupun tertulis sebaiknya menyesuaikan dengan waktu dan kondisi, serta jenis materi yang akan diujikan. Sehingga pemberian ins-trumen efektif jika dapat mengukur indikator dan tercapainya tujuan pembelajaran.

\section{DAFTAR PUSTAKA}

Arikunto, S. (2010). Prosedur penelitian suatu pendekatan praktik. Jakarta: Rineka Cipta.

Devira, R. (2016). Peningkatan keterampilan berbicara menggunakan metode investigasi kelompok peserta didik kelas IX SMP negeri 2 bukittinggi. Jurnal Kiprah, 4(1),1-14.

Elfiza, R. (2017). The effect of using adventure game and picture to improve extroverted students' speaking skill. Jurnal Kiprah. 5(1), 42-54.

Fitriani. (2013). Perbandingan hasil belajar biologi siswa SMA AL Islam 3 surakarta melalui tes tulis dan tes lisan ditinjau dari konsep diri. (Naskah Publikasi). FKIP Universitas Muhammadiyah Surakarta.

Kumara, M. (2001). Dampak kemampuan verbal terhadap kualitas ekspresi tulis.Jurnal Psikologi, 1, 35-40.

Murniayudi, H., Mustadi, A., \& Jerusalem, M. A. (2018). Reciprocal teaching: Sebuah inovasi pembelajaran abad 21 untuk meningkatkan pemahaman konsep mahasiswa PGSD, Premiere Educandum, Jurnal Pendidikan Dasar dan Pembelajaran, 8(2), 173-184. https://doi.org/10.25273/pe.v8i2.33 08.

Muttaqin, Zaenal, M., \&Kusaeri. (2017). Pengembangan instrumen penilaian tes tertulis bentuk uraian untuk pembelajaran PAI berbasis masalah 
materi fiqih. Jurnal Tatsqif, 15(1), $1-23$.

Perkasa, A., \& Izzati, N. (2018). Analisis kesalahan siswa dalam menyelesaikan soal tentang membaca denah. Jurnal Kiprah, $6(2), 48-53$.

Priyatno, D. (2010). Teknik mudah dan cepat melakukan analisis data penelitian dengan SPSS. Yogyakarta: Gaya Media

Purwanta. (2010). Penggunaan penilaian berbasis kelas untuk meningkatkan kualitas proses dan hasil belajar siswa kelas IV SD negeri samirono yogyakarta pada mata pelajaran IPS. Jurnal Penelitian.13(2), 147168.

Rahman, F., et all. (2011). Impact of discussion method on students' performance. International Journal of Business and Social Science, (2)7, 84-94.

Rokhmawan, \&Adhy, D. (2009). Perbedaan hasil belajar antara tes tertulis dengan tes lisan pokok bahasan konstruksi pondasi dangkal pada siswa program keahlian teknik gambar bangunan tingkat X SMK negeri 5 semarang tahun ajaran 2008/2009. (Skripsi). FK Universitas Negeri Semarang.

Ruhimat, M. (2018). Kompetensi pembuatan instrumen peng-ukuran hasil belajar oleh guru IPS smp di kota bandung. Jurnal Lentera Pendidikan. 21(2), 176-187.

Saidah, K. (2016). Analisis kesesuaian Instrumen penilaian IPS pada buku guru kelas V tema "sejarah peradaban bangsa Indonesia" dengan kompetensi dan prinsip penilaian IPS SD kurikulum 2013. Jurnal Pendidikan Dasar Nusantara, 2(1), 21-31.

Samad \& Arshad, A. (2013). The use of portofolio as an assessment tool in the malaysian L2 classroom. International Journal of English Language Education, 1(1), 94-108.

Sands, D. (2014). Concepts and conceptual understanding: what are we talking about? $\quad$ 10(I), 7-11. https://doi.org/10.29311/ndtps.v0i1 0.510

Silviriyanti, D. (2019). Penerapan Pembelajaran Kooperatif Model Think-Pair-Square (TPS) Untuk Meningkatkan Aktivitas dan Prestasi Belajar Siswa Kelas VIIID Semester II SMP Negeri 20 Malang. Jurnal Inteligensi: Ilmu Pendidikan, UNITRI Press. 1(1),16-17. http://dx.doi.org/10.33366/ilg.v1i2. 1353

Sukardi. (2019). Metode penelitian pendidikan: Kompetensi dan praktiknya. Jakarta: Bumi Aksara.

Tyaningsih, R. Y. (2016). Keteram-pilan komunikasi lisan calon guru matematika pada mata kuliah proses belajar mengajar (MK PBM). Jurnal Math Eduacator Nusantara, 2(1), 55-66.

Wicaksono, H., Arini, E., \& Kurnia, B. (2016). Pelaksanaan evaluasi pembelajaran IPS berbasis KTSP kelas V. Jurnal Kreatif, 54-62. 